\title{
REALIZACJA INWESTYCJI SPOŁECZNYCH W POLSCE W KONTEKŚCIE ZAŁOŻEŃ POLITYKI SPOŁECZNEJ UNII EUROPEJSKIEJ
}

\author{
IMPLEMENTATION OF SOCIAL INVESTMENT IN POLAND \\ IN THE CONTEXT OF PRIORITIES OF THE EUROPEAN \\ UNION'S SOCIAL POLICY
}

Małgorzata Michalewska-Pawlak* @]

Dorota Moroń**

Monika Klimowicz ${ }^{* * *}$

\begin{abstract}
ABSTRAKT
Celem artykułu jest zaprezentowanie wpływu priorytetów i instrumentów polityki społecznej Unii Europejskiej na realizację podejścia inwestycyjnego w politykach społecznych państw członkowskich na przykładzie Polski. Przedmiotem badań są cele społeczne Unii Europejskiej zdefiniowane w strategii Europa 2020 oraz Pakiecie Inwestycji Społecznych, implementowane za pomocą otwartej metody koordynacji i interwencji Europejskiego Funduszu Społecznego w państwach członkowskich Unii Europejskiej. W konkluzji stwierdzono, że proces europeizacji polityk społecznych państw członkowskich UE, na przykładzie Polski, $\mathrm{w}$ odniesieniu do implementacji paradygmatu inwestycyjnego, ma ograniczony charakter.
\end{abstract}

\section{ABSTRACT}

The main aim of the paper is to describe the influence of priorities and instruments of the European Union's social policy on implementation of investment approach in social policies of the EU member states based on the Polish example. The research refers to the EU social goals defined in the Europe 2020 strategy and in the Social Investment Package. They have been implemented by the open method of coordination and the European Social Fund intervention in the EU member states. The conclusion is that the Europeanization of social policies of the EU member states based on the Polish example by the investment paradigm implementation have had limited scope.

* Uniwersytet Wrocławski, Wydział Nauk Społecznych.

** Uniwersytet Wrocławski, Wydział Nauk Społecznych.

*** Uniwersytet Wrocławski, Wydział Nauk Społecznych. 
Słowa kluczowe: europeizacja; inwestycje społeczne; strategia Europa 2020; Unia Europejska; Horyzont 2020
Keywords: Europeanization; social investment; Europe 2020 strategy; European Union; Horizon 2020

\section{WPROWADZENIE}

Paradygmat inwestycji społecznych staje się dziś istotnym kierunkiem realizacji działań z zakresu polityki społecznej i gospodarczej państw opiekuńczych w Europie oraz stanowi kluczowy punkt odniesienia polityki społecznej Unii Europejskiej. Postrzegany jest jako alternatywna dla tradycyjnych welfare state, odpowiedź na kryzys finansów publicznych i nowe wyzwania społeczne, identyfikowane w krajach Unii Europejskiej (UE).

Celem niniejszego artykułu jest analiza wpływu priorytetów i instrumentów polityki społecznej UE na realizację podejścia inwestycyjnego w politykach społecznych państw członkowskich na przykładzie Polski. Zaprezentowane zostaną tu założenia paradygmatu inwestycji społecznych UE, silnie związanego z realizacją założeń aktualnej strategii rozwojowej Europa 2020 oraz wytycznych zawartych w Pakiecie Inwestycji Społecznych (PIS), zaproponowanych przez Komisję Europejską (KE) w 2013 roku. Polityka społeczna stanowi obszar współpracy państw członkowskich UE, a jej realizacja na poziomie ponadnarodowym wyklucza stosowanie metody wspólnotowej, zarówno w wymiarze decyzyjnym, jak i implementacyjnym. Stąd w artykule zostanie wskazana otwarta metoda koordynacji (OMK) jako instrument realizacji unijnego paradygmatu proinwestycyjnego $\mathrm{w}$ polityce społecznej na poziomie narodowym, $\mathrm{z}$ drugiej zaś, wpływ Europejskiego Funduszu Społecznego (EFS) jako najważniejszego instrumentu realizacji celów społecznych UE, zawartych w strategii Europa 2020 oraz PIS. Główna hipoteza prowadzonych analiz zakłada zatem, że państwa członkowskie UE, w tym także Polska, chcące korzystać $\mathrm{z}$ finansowego wsparcia EFS, zobligowane są do uwzględnienia założeń paradygmatu proinwestycyjnego, szczególnie w odniesieniu do podnoszenia jakości i produktywności kapitału ludzkiego w cyklu życia jednostki, integracji zawodowej i społecznej, inwestycji w dzieci i młodzież, edukacji i przeciwdziałania wykluczeniu społecznemu oraz ubóstwu. W celu weryfikacji przyjętej hipotezy badawczej sformułowane zostały dwa kluczowe pytania badawcze. Pierwsze z nich odnosi się do charakterystyki instrumentów wpływu procesu europeizacji na narodowe polityki społeczne państw UE, w kierunku implementacji paradygmatu inwestycyjnego, drugie 
natomiast dotyczy uwarunkowań i zakresu, w jakim państwa dokonują zmian w narodowych politykach społecznych pod wpływem oddziaływania tychże instrumentów. Warto na wstępie poczynić kluczowe założenie, że europeizacja krajowych polityk społecznych w każdym państwie będzie zachodzić w odmienny sposób, ze względu na zróżnicowane uwarunkowania historyczne, kulturowe, polityczne i ekonomiczne, występujące w poszczególnych krajach, które mają wpływ na zasięg, siłę i efekty procesów europeizacji, a także reakcję narodowych systemów społecznych na oddziaływanie polityki UE w tym zakresie. Dlatego niżej zaprezentowana analiza odnosi się do konkretnego studium przypadku, jakim jest Polska, a jej wyniki nie mają charakteru uniwersalnego w stosunku do pozostałych państw członkowskich UE. Teza ta znajduje odzwierciedlenie w fakcie, iż część państw członkowskich UE, między innymi kraje skandynawskie, realizuje inwestycje społeczne w większym zakresie niż wynika to z zaleceń PIS (Klimowicz, Michalewska-Pawlak, Moroń, 2018, s. 169). Niemniej jednak niniejsza analiza wskazuje na możliwości implementacyjne inwestycji społecznych promowanych w polityce UE na krajowy poziom organizacji społecznej i politycznej państw.

Artykuł zawiera wyniki badań empirycznych prowadzonych w ramach projektu badawczego Innovative Social Investment Strenghtening Communities in Europe, sfinansowanego przez KE z Programu Horyzont 2020. Analiza polityki społecznej UE i Polski została przeprowadzona w oparciu dokumenty o charakterze strategicznym i operacyjnym z poziomu ponadnarodowego i krajowego. Treść tekstu zawiera także ustalenia zawarte w najnowszej literaturze przedmiotu, odnoszącej się do inwestycji społecznych.

\section{METODA OTWARTEJ KOORDYNACJI W ZARZĄDZANIU ROZWOJEM SPOŁECZNYM W UNII EUROPEJSKIEJ}

Niezależnie od aktualnego poziomu rozwoju społecznego poszczególnych państw członkowskich UE zaobserwować można określony katalog wyzwań gospodarczych, społecznych i kulturowych, które wpływają na zmiany w funkcjonowaniu państw opiekuńczych i systemów zabezpieczenia społecznego w Europie. W śród nich pojawiają się chociażby te, dotyczące wzrostu presji konkurencyjności i efektywności gospodarczej, której sprostać może między innymi wysokiej jakości kapitał ludzki, spadku dzietności i wydłużenia przeciętnego trwania życia, migracji wewnętrznych i zewnętrznych na terytorium 
UE oraz towarzyszące im kwestie związane $\mathrm{z}$ integracją społeczno-kulturową czy zmiana tradycyjnego modelu rodziny i ról społecznych kobiet i mężczyzn. Dotychczasowe zróżnicowane modele polityki społecznej implementowane przez poszczególne państwa członkowskie UE okazały się niewystarczające wobec narastających wyzwań i nowych ryzyk społecznych z nimi związanych (Bonoli, 2005; Grewiński, 2015, s. 58-59).

Współpraca między państwami oraz instytucjami UE na rzecz zapewnienia optymalnych warunków rozwoju społecznego uległa intensyfikacji wraz z pogłębianiem się procesów integracji europejskiej. Pierwsze regulacje traktatowe dotyczące spraw społecznych wprowadzone zostały na mocy Traktatu z Maastricht, podpisanego w 1992 r., ustanawiającego Unię Gospodarczo-Walutową, który stanowił zapowiedź zaangażowania UE w tym obszarze, rozwijanego w kolejnych traktatach (Mucha-Leszko, 2016, s. 198). Obecnie obowiązujący od 2009 r. Traktat o Funkcjonowaniu Unii Europejskiej (TFUE) w artykule 4 wskazuje, że polityka społeczna stanowi obszar kompetencji dzielonych pomiędzy UE a państwami członkowskimi. UE może podejmować działania na rzecz koordynacji polityki społecznej państw członkowskich, natomiast analizując szczegółowe obszary tematyczne związane z zarządzaniem rozwojem społecznym na poziomie ponadnarodowym, należy wskazać, iż obowiązują w nich odmienne procedury decyzyjne. Tytuł X TFUE dedykowany jest polityce społecznej i dotyczy między innymi obszarów, w których UE wspiera i uzupełnia działania państw' ${ }^{1}$. Szczególną rolę w zakresie koordynacji współpracy między państwami członkowskimi w dziedzinach takich jak: zatrudnienie, prawo pracy i warunki pracy, kształcenie i doskonalenie zawodowe, zabezpieczenie społeczne, ochrona przed wypadkami i chorobami zawodowymi, higiena pracy oraz prawo zrzeszania się w związki zawodowe i rokowań zbiorowych między pracodawcami i pracownikami odgrywa Komisja Europejska (art. 155 TFUE). Jest ona jednocześnie promotorem paradygmatu inwestycyjnego $\mathrm{w}$ ramach swoich działań o charakterze koordynacyjnym.

1 W art. 153 TFUE wymienione zostały: polepszenie w szczególności środowiska pacy w celu ochrony zdrowia i bezpieczeństwa pracowników, warunki pracy, zabezpieczenie społeczne i ochrona socjalna pracowników, ochrona pracowników w przypadku wypowiedzenia umowy o pracę, informacja i konsultacja z pracownikami, reprezentacja i obrona zbiorowa interesów pracowników i pracodawców, w tym współzarządzanie, warunki zatrudnienia obywateli państw trzecich legalnie przebywających na terytorium Unii, integracja osób wykluczonych z rynku pracy, równość mężczyzn i kobiet w odniesieniu do ich szans na rynku pracy i traktowania w pracy, zwalczanie wykluczenia społecznego, modernizacja systemów ochrony socjalnej. 
$\mathrm{Na}$ forum UE dyskusja nad paradygmatem inwestycji społecznych jako nowym modelem zarządzania rozwojem społecznym została zapoczątkowana przez Prezydencję Belgijską w 2001 r. (Leibetseder, 2017, s. 2), natomiast zainteresowanie nową perspektywą realizacji polityki społecznej, która zwiększa presję na efektywność i skuteczność stosowanych rozwiązań, wzrosło w wyniku kryzysu ekonomicznego, który dotknął Europę w 2009 r. Od tego momentu zarówno instytucje UE, jak i państwa członkowskie poszukują bardziej optymalnych rozwiązań dla realizacji rozwoju społecznego, przy istniejących ograniczonych zasobach finansowych. Implementacja podejścia inwestycyjnego w opinii instytucji UE ma przygotować Europejczyków do zmian zgodnie z zasadą przewidywania ich kierunków i zapobiegania ich ewentualnym negatywnym skutkom.

$\mathrm{W}$ obszarach tematycznych nieobjętych regulacjami prawa unijnego, dla wzmocnienia i usprawnienia współpracy na rzecz rozwoju społecznego, państwa członkowskie stosują OMK, która swoją genezą sięga ustanowienia Europejskiej Strategii Zatrudniania. Formalnie, jako metoda zarządzania, została ona zaakceptowana przez Radę Europejską podczas szczytu w Lizbonie w 2000 r. (Armstrong, 2010; Pietrzyk, 2013, s. 217-226).

OMK jest metodą zarządzania, która ma na celu intensyfikację współpracy między państwami członkowskimi UE, bez konieczności tworzenia norm prawa unijnego w obszarze tej współpracy oraz zmian w prawie krajowym podejmujących ją państw. Ma ona zastosowanie w tych dziedzinach, w których państwa są zainteresowane rozwijaniem współdziałania w oparciu o procedury międzyrządowe. Stanowi zatem alternatywę dla podejścia wspólnotowego w obszarach tematycznych, $\mathrm{w}$ których $\mathrm{z}$ różnych względów,integracja nie osiągnęła poziomu ponadnarodowego i nie zostały wypracowane wspólne i jednolite rozwiązania prawne obowiązujące we wszystkich państwach członkowskich (Borrás, Jacobsson, 2004). Ma ona umożliwiać realizację wspólnych celów państw poprzez konkretne działania obejmujące wyznaczenie wspólnych wskaźników realizacji celów i punktów odniesienia, prowadzenie okresowych przeglądów, obserwacji i ewaluacji tych działań oraz wzajemnego uczenia się i wymiany dobrych praktyk (European Council, 2000).

OMK funkcjonuje w obszarze zarządzania rozwojem społecznym i została implementowana do realizacji strategii Europa 2020 oraz PIS. Tym samym koordynacja współpracy między państwami członkowskimi w obszarze implementacji podejścia inwestycyjnego stanowi element europeizacji krajowych polityk społecznych państw członkowskich. Europeizacja w kontekście implementacji paradygmatu inwestycyjnego w państwach członkowskich UE rozumiana jest 
jako transfer wartości lub standardów z poziomu europejskiego na poziom narodowy, a następnie ich zastosowanie i efekt wywołany taką implementacją (Ruszkowski, 2007, s. 48) ${ }^{2}$. Dlatego dalszej analizy wymaga kwestia, na ile stosowane metody i instrumenty zarządzania rozwojem społecznym UE wywierają europeizacyjny wpływ na implementację podejścia inwestycyjnego na poziomie narodowym na przykładzie Polski.

\section{ZAŁOŻENIA PARADYGMATU INWESTYCJI SPOŁECZNYCH W POLITYCE SPOŁECZNEJ UE}

Wzrost znaczenia paradygmatu inwestycji społecznych wynika z modyfikacji celów polityki UE, która opiera się na skorelowaniu priorytetów polityki społecznej z celami polityki gospodarczej. W związku z tym założeniem polityka społeczna od $2014 \mathrm{r}$. ma charakter proinwestycyjny, w tym również w wymiarze realizacji celu UE, jakim jest dążenie do spójności społecznej pomiędzy państwami i regionami. Zmiana ukierunkowania instrumentów polityki spójności z narzędzi rozwojowych na proinwestycyjne sprawiła, że możliwe było przypisanie im, w tym między innymi EFS, znaczącej roli w finansowaniu realizacji strategii Europa 2020 (Moroń, Klimowicz, 2016, s. 69). Założeniem strategii Europa 2020 jest wspieranie inteligentnego, zrównoważonego i sprzyjającego włączeniu społecznemu modelu rozwoju w UE. Proces osiągania 5 celów tematycznych w dziedzinach zatrudnienia, innowacji, włączenia społecznego oraz klimatu i energii został zaprojektowany tak, aby państwa członkowskie wpisały te cele do projektowanych na poziomie krajowym działań (KE, 2010).

W przypadku Polski wskaźnik dotyczący wzrostu poziomu aktywności zawodowej jest niższy w odniesieniu dla wartości przyjętych dla UE-27. Wynika to $\mathrm{z}$ faktu, iż w 2010 nie był on wysoki, natomiast w świetle danych z 2016 roku można spodziewać się, iż Polsce uda się przekroczyć wskazany pułap min. 71\%. Trzeba zauważyć, że wzrost ten warunkowany jest nie tylko skuteczną polityką społeczną, ale także sytuacją gospodarczą i zmianami zachodzącymi na rynku pracy w wyniku procesów rynkowych.

2 W literaturze przedmiotu można spotkać wiele rożnych ujęć koncepcyjnych procesów europeizacji, obejmujących także analizę jej wymiarów i efektów. Na potrzeby artykułu zastosowano definicję odnoszącą się do charakterystyki relacji pomiędzy UE a państwami członkowskimi w wymiarze top-down. Szerzej na temat koncepcji i definicji procesów europeizacji patrz: Buller, Gamble, 2002; Exadaktylos, Radaelli, 2009; Ladrech, 2010. 


\begin{tabular}{|c|c|c|c|c|c|}
\hline 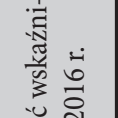 & $\frac{\frac{\pi}{\pi}}{0}$ & $\hat{\sigma}$ & in & $\begin{array}{l}b \\
f\end{array}$ & $\stackrel{H}{6}$ \\
\hline 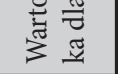 & $\stackrel{5}{\sim} \stackrel{\infty}{\sim}$ & $\stackrel{0}{i}$ & $\hat{0}$ & बे & $\stackrel{12}{0}$ \\
\hline$u$ & $\frac{\pi}{\frac{\pi}{\pi}}$ & $\stackrel{m}{0}$ & Ê & $\stackrel{\infty}{\text { mे }}$ & $\stackrel{m}{\sim}$ \\
\hline 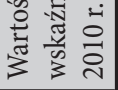 & さ & $\begin{array}{l}0 \\
\infty 0 \\
\infty\end{array}$ & ले & $\stackrel{\infty}{n}$ & $\stackrel{m}{\ominus}$ \\
\hline 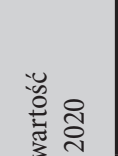 & $\frac{\frac{\pi}{\pi}}{0}$ & 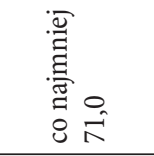 & $\stackrel{12}{f}$ & $\begin{array}{l}0 \\
\stackrel{5}{4}\end{array}$ & 1 \\
\hline 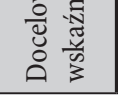 & $\begin{array}{l}\infty \\
\text { 剀 } \\
\text { S }\end{array}$ & 옷 & $\stackrel{0}{\circ}$ & @) & 1 \\
\hline 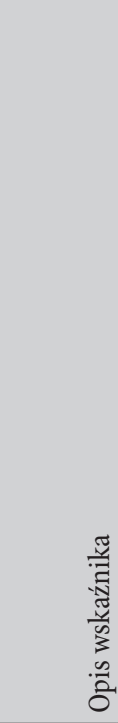 & & 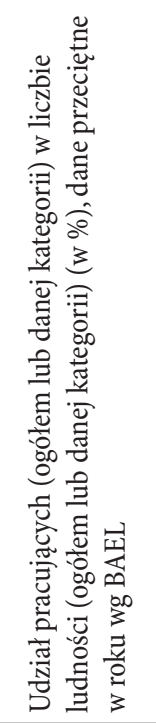 & 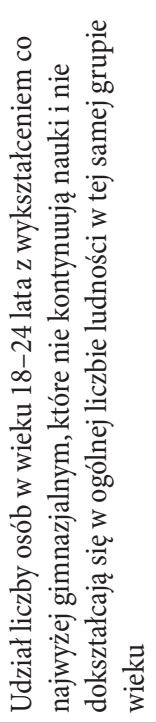 & 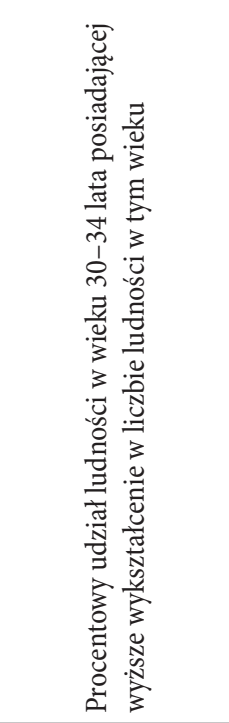 & 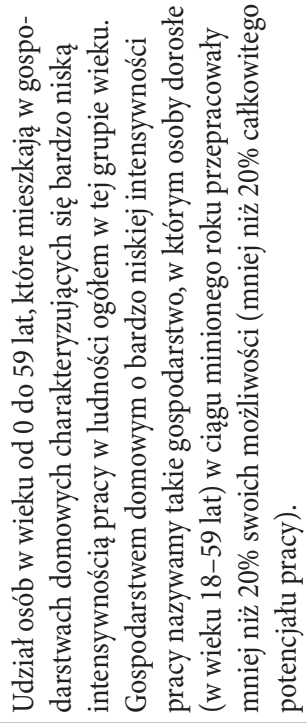 \\
\hline $\begin{array}{l}\text { त्च } \\
\text { त्ञ } \\
\text { जै } \\
3\end{array}$ & & 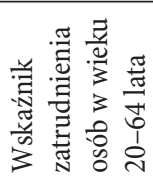 & 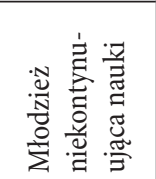 & 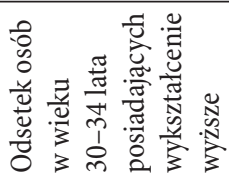 & 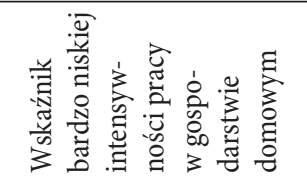 \\
\hline $\begin{array}{l}\text { స్ } \\
\text { ०ै } \\
0\end{array}$ & & 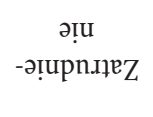 & \multicolumn{2}{|c|}{ ецюеупря } & 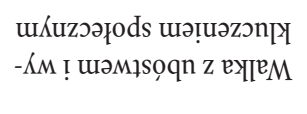 \\
\hline
\end{tabular}




\begin{tabular}{|c|c|c|c|c|}
\hline \multirow{2}{*}{ 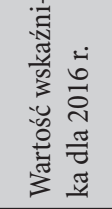 } & $\begin{array}{l}\frac{\pi}{\pi} \\
\frac{\pi}{0} \\
\stackrel{2}{2}\end{array}$ & $\hat{\vec{\lambda}}$ & $\stackrel{m}{=}$ & $\hat{\sigma}$ \\
\hline & 嵓 & $\hat{\tilde{n}}$ & $\stackrel{n}{=}$ & $\stackrel{2}{\sim}$ \\
\hline \multirow{2}{*}{ 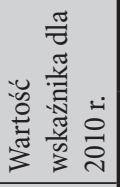 } & $\begin{array}{l}\frac{\pi}{3} \\
\frac{\pi}{0} \\
2\end{array}$ & $\begin{array}{l}\infty \\
\hat{\sim} \\
\end{array}$ & $\begin{array}{l}0 \\
\cong\end{array}$ & $\stackrel{\sim}{ \pm}$ \\
\hline & $\begin{array}{l}\widehat{ } \\
\text { పे }\end{array}$ & $\stackrel{\infty}{\hat{\imath}}$ & in & $\stackrel{+}{\infty}$ \\
\hline \multirow{2}{*}{ 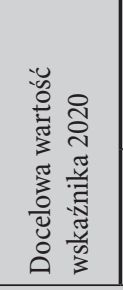 } & $\begin{array}{l}\frac{\pi}{\sqrt[3]{3}} \\
\frac{\overrightarrow{0}}{0} \\
\stackrel{2}{1}\end{array}$ & 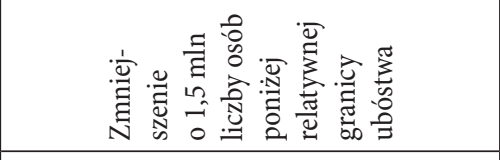 & 1 & 1 \\
\hline & 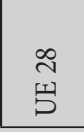 & 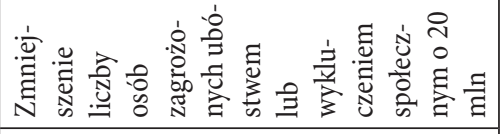 & 1 & 1 \\
\hline \multicolumn{2}{|c|}{ 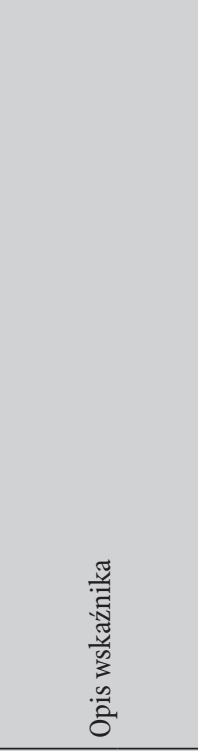 } & 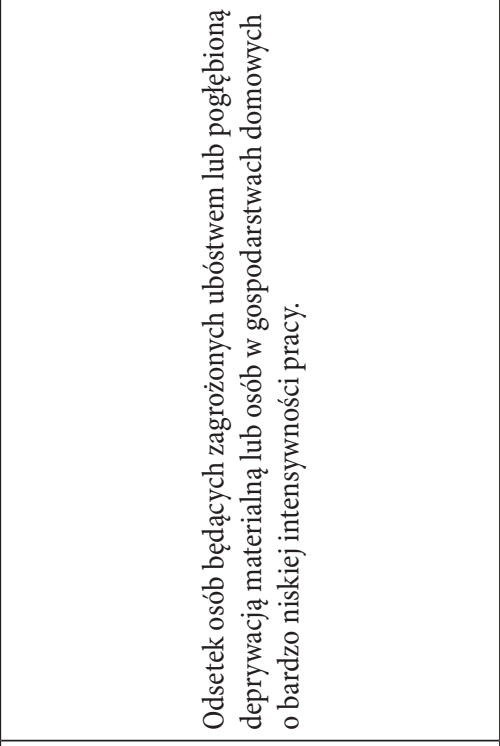 & 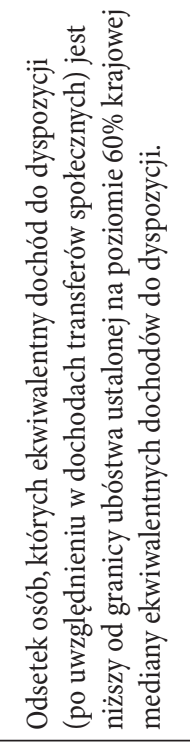 & 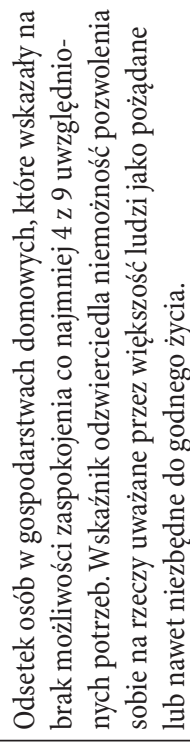 \\
\hline 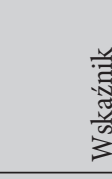 & & 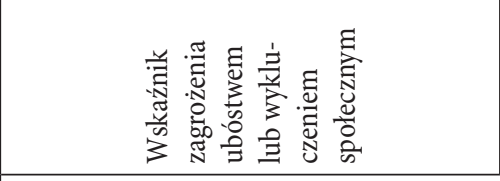 & 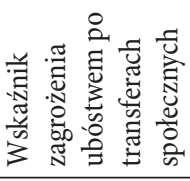 & 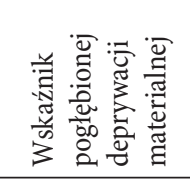 \\
\hline \multicolumn{2}{|c|}{$\begin{array}{l}\text { స్్ㅐ } \\
\text { مै }\end{array}$} & \multicolumn{3}{|c|}{ 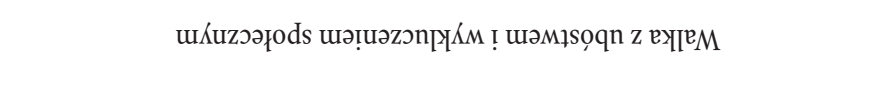 } \\
\hline
\end{tabular}


W przypadku mierników odnoszących się do edukacji Polska wypada znacznie lepiej niż średnia unijna, zarówno pod względem odsetka ludności z wykształceniem wyższym, jak i osobami przedwcześnie kończącymi edukację. Tutaj z kolei trzeba zauważyć, iż nie tylko poziom wykształcenia wpływać będzie na lepsze szanse i pespektywy zawodowe ludności, ale przede wszystkim jakość kształcenia i dostosowanie go do wymogów i potrzeb rynku pracy. Niestety wskaźniki przyjęte w strategii nie odnoszą się do powyższych danych.

W przypadku redukcji ubóstwa i zagrożenia ubóstwem przyjęty miernik jest zbliżony procentowo do poziomu wygenerowanego dla całej UE, co oznaczać może, iż poziom życia większości Polaków systematycznie wzrasta.

Dzięki OMK, poprzez proces wymiany koncepcji politycznych i wzajemnego uczenia się, a jednocześnie umożliwienie państwom członkowskim określanie własnej polityki prowadzącej do osiągnięcia tych celów, KE monitoruje postępy w osiąganiu wyznaczonych w strategii Europa 2020 celów. W ramach tej procedury państwa członkowskie przedkładają co dwa lata Krajowe Raporty Społeczne, zawierające informacje na temat działań w obszarze zabezpieczenia społecznego, a w latach, w których nie powstają KRS, sprawozdają stan podjętych działań w ramach syntetycznych Strategicznych Raportów Społecznych.

Warto zwrócić uwagę, iż w 2013 roku KE opublikowała wytyczne w formie PIS, dotyczące pożądanych kierunków zmian od tradycyjnego modelu polityki społecznej do paradygmatu inwestycyjnego (Michalewska-Pawlak, 2017, s. 100). Proponowane wytyczne mają wspierać państwa członkowskie w osiągnięciu celów strategii Europa 2020, poprzez powiązanie realizowanych reform w ramach krajowych polityk społecznych z wdrażaniem funduszy unijnych, w tym EFS.

PIS określił ramy polityczne służące ukierunkowaniu działań państw członkowskich na inwestycje społeczne w celu zapewnienia adekwatności i stabilności budżetów przeznaczonych na politykę społeczną, zgodnie z rezolucją Parlamentu Europejskiego w sprawie paktu na rzecz inwestycji społecznych (PE, 2012). KE wezwała państwa członkowskie UE do wyznaczenia priorytetów w zakresie inwestycji społecznych i do zmodernizowania swoich systemów opieki społecznej (Pazderski, 2017, s. 9).

Jednocześnie PIS oparto na ramach prawnych zaproponowanych w celu realizacji polityki spójności w pespektywie finansowej na lata 2014-2020, a w szczególności na rozwiązaniu zakładającym wydatkowanie co najmniej 20\% środków z EFS w każdym państwie członkowskim na promowanie włączenia społecznego i zwalczanie ubóstwa (EC, 2013). Podkreślono w nim znaczenie i wagę stosowania innowacyjnych rozwiązań finansowych i prawnych oraz 
instytucjonalnych, takich jak: mikrofinanse, odpłatność za usługi na podstawie rezultatów, obligacje wpływu społecznego (ang. Social Impact Bonds), różne formy wsparcia przedsiębiorców społecznych oraz trójsektorowe partnerstwa (publiczno-prywatno-pozarządowe). Jednym z najważniejszych załączników do tego dokumentu było zalecenie KE Inwestowanie $w$ dzieci: przerwanie cyklu marginalizacji. Przedstawiono w nim zintegrowaną i wszechstronną strategię mającą na celu przeciwdziałanie ubóstwu dzieci. Istotą dokumentu jest zobowiązanie państw członkowskich UE do zapewnienia dzieciom środowiska rodzinnego dysponującego zasobami niezbędnymi do zaspokojenia ich podstawowych potrzeb. Walka z ubóstwem dzieci w oczywisty sposób wiąże się z sytuacją rodzin - decydujące znaczenie ma godna praca rodziców i godziwe wynagrodzenie, a także elastyczne warunki zatrudnienia, dzięki którym rodzice mogą łączyć aktywność zawodową z życiem rodzinnym oraz spędzać wystarczająco dużo czasu ze swoimi dziećmi (D’Addato, Williams, 2013, s. 6).

Inne dokumenty towarzyszące nie miały już takiego statusu, lecz charakter bardziej roboczy i dotyczyły lepszego wdrażania aktywnej integracji, opieki długoterminowej (wyzwania i warianty rozwiązań), przeciwdziałania problemowi bezdomności, inwestowania w zdrowie (poprawa wydajności i skuteczności systemów opieki zdrowotnej przy ograniczonym budżecie) oraz roli EFS we wdrażaniu działań o charakterze inwestycji społecznych (Szarfenberg, 2014, s. 27).

Paradygmat proinwestycyjny EFS na lata 2014-2020 przejawia się w postawieniu państwom członkowskim, chcącym korzystać $\mathrm{z}$ tego instrumentu, warunków wstępnych - ex-ante. Dotyczą one w głównej mierze konieczności przedstawienia dokumentów strategicznych dotyczących m.in. aktywnej polityki rynku pracy, polityki zdrowotnej, polityki starzenia się, polityki równości, polityki na rzecz ograniczenia ubóstwa czy polityki edukacyjnej (zob. PE i Rada UE, 2013, art. 19). Dodatkowe warunki wstępne dotyczą kwestii związanych $\mathrm{z}$ administracyjnymi możliwościami wdrażania EFS.

Działania finansowane z EFS mają prowadzić do „poprawy możliwości zatrudniania pracowników w ramach rynku wewnętrznego, [...] ułatwienia zatrudniania pracowników i zwiększania ich mobilności geograficznej i zawodowej wewnątrz Unii, jak również do ułatwienia im dostosowania się do zmian w przemyśle i systemach produkcyjnych, zwłaszcza przez kształcenie zawodowe i przekwalifikowanie" (Traktat o funkcjonowaniu UE, art. 162). 


\section{POLITYKA INWESTYCJI SPOŁECZNYCH W POLSCE W KONTEKŚCIE PROCESÓW EUROPEIZACJI}

Zarówno pojęcie, jak i koncepcja inwestycji społecznych promowana przez UE generalnie nie jest prezentowana i szeroko stosowana przez instytucje publiczne, realizujące politykę społeczną w Polsce. Widoczny jest brak odwołania do tej koncepcji w krajowych strategiach i programach wytyczających kierunki działań w sferze polityki społecznej i implementujących założenia strategii Europa 2020 i PIS (Wiktorska-Święcka i in., 2015). Pojęcie inwestycji jest używane głównie w odniesieniu do projektów infrastrukturalnych, w tym również w sferze infrastruktury społecznej. Bywa ono także odnoszone do działań w sferze polityki społecznej, chociaż bez użycia przymiotnika „społeczne”, jak choćby w strategii Polska 2030. Trzecia fala nowoczesności. Dtugookresowa Strategia Rozwoju Kraju, która wskazuje na inwestycje miękkie w edukację, edukację wyższą, naukę, zdrowie jako działania na rzecz wzmacniania i rozwoju kapitału ludzkiego, które przyczynią się do lepszego funkcjonowania osób na rynku pracy (MAiC, 2013, s. 17, 67, 75, 83, 114). W Strategii Rozwoju Kraju 2020 z kolei pojawiają się inwestycje miękkie jako strategiczne zadania państwa w perspektywie 2020 roku. Wskazywane są tutaj rozwiązania w zakresie polityki prorodzinnej, edukacji i szkolnictwa wyższego, zdrowia publicznego i opieki zdrowotnej, rynku pracy oraz wspierania kapitału społecznego (MRR, 2012, s. 2000). Strategia Rozwoju Kapitału Ludzkiego 2020 wskazuje na konieczność inwestycji w edukację na poziomie wyższym i kadry ochrony zdrowia (MPiPS, 2013a, s. 54, 61), jednakże nie odnosi się szerzej do kwestii inwestycji o charakterze społecznym. Podobnie odwołań do inwestycji, czy inwestycji społecznych nie ma w Strategii Rozwoju Kapitału Społecznego 2020 (MKiDN, 2013), Krajowym Programie Przeciwdziałania Ubóstwu i Wykluczeniu Społecznemu 2020. Nowy wymiar aktywnej integracji (MPiPS, 2013b), Krajowym Planie Działań na rzecz Zatrudnienia na lata 2015-2017 (MPiPS, 2015) czy Założeniach Długofalowej Polityki Senioralnej w Polsce na lata 2014-2020 (MPiPS, 2013c), jednakże dokumenty te proponują działania, które mają wymiar inwestycyjny w rozumieniu prezentowanym przez UE i stosowanym $w$ innych państwach członkowskich (Wiktorska-Święcka i in., 2017; Wiktorska-Święcka i in., 2016; EC, 2018). Jako inwestycje są tu bowiem ujmowane działania na rzecz rozwijania zasobów kapitału ludzkiego i społecznego, szczególnie wzmacniania wiedzy, umiejętności i kompetencji wykorzystywanych w życiu społecznym i zawodowym, pełnego wykorzystywania kapitału ludzkiego na rynku pracy, a także wzmacniania 
kapitału ludzkiego dla zapobiegania przyszłym potencjalnym problemom i negatywnym zjawiskom społecznym.

Również w politycznych analizach realizacji działań z zakresu polityki społecznej rzadko bezpośrednio wskazywany jest jej inwestycyjny charakter. Przykładem odwołania do inwestycji społecznych może być raport dotyczący działań z zakresu polityki rodzinnej Rodzina najlepsza inwestycja (MRPiPS, 2017). Wskazano w nim, że „Polityka na rzecz rodzin to inwestycja, która opłaca się nam jako wspólnocie. [...] Jesteśmy w czołówce państw europejskich, które inwestują w rodzinę" (MRPiPS, 2017, s. 19). Jako inwestycje społeczne w rodzinę wymienione zostały takie działania, jak: Program „Rodzina 500+”, Program „Za życiem”, rozwój opieki nad małym dzieckiem, wspieranie rodzin wielodzietnych, reforma edukacji, Program „Mieszkanie+”, podniesienie minimalnego wynagrodzenia za pracę i wprowadzenie minimalnej stawki godzinowej, przywrócenie wieku emerytalnego 60 lat dla kobiet $i 65$ lat dla mężczyzn oraz wsparcie seniorów w ramach Programu „Senior+” (MRPiPS, 2017). Część z tych rozwiązań ma bezsprzecznie inwestycyjny charakter $\mathrm{w}$ rozumieniu nadanym inwestycjom społecznym przez UE, natomiast niektóre zdecydowanie nie wpisują się w ten paradygmat, jak choćby przywrócenie wieku emerytalnego 60 lat dla kobiet i 65 lat dla mężczyzn. Wydaje się więc, że paradygmat inwestycji społecznych nie stanowi ram dla kreowania nowych działań w sferze polityki społecznej na poziomie centralnym.

Jednocześnie wdrażaniu inwestycji społecznych sprzyjają projekty współfinansowane z EFS, co wynika z celów unijnej polityki społecznej i ich implementowania na poziomie krajowym. EFS wspiera finansowo inwestycje w ludzi, przede wszystkim w kontekście ich funkcjonowania - aktualnego i przyszłego na rynku pracy, realizując tym samym założenia określone w PIS.

Środki dostępne w ramach EFS dla Polski na lata 2014-2020 wynoszą 13,2 mld euro i alokowane są na dwóch poziomach: krajowym i regionalnym, co umożliwia lepsze ukierunkowanie interwencji funduszu na zaspokojenie specyficznych potrzeb rozwojowych mieszkańców poszczególnych regionów. Aktualnie są one rozdysponowywane w ramach POWER 2014-2020-4,4 mld euro, co stanowi $34 \%$ całkowitego budżetu EFS oraz w ramach szesnastu RPO 8,8 mld euro, co stanowi z kolei 66\% dostępnej dla Polski alokacji EFS (MPRiPS, Europejski...). Dodatkowo działania te uzupełniane są inwestycjami społecznymi realizowanymi w ramach innych programów, m.in. Programu Rozwoju Obszarów Wiejskich 2014-2020 czy programów ramowych, jak Horyzont 2020 lub Erasmus+, finansowanymi z innych funduszy pochodzących $\mathrm{z}$ budżetu UE (Portal..., 2018). 
POWER 2014-2020 odnosi się do kluczowych obszarów inwestowania w ludzi - w jego ramach współfinansowane są projekty wspierające osoby młode na rynku pracy, działania na rzecz włączenia społecznego i zawodowego grup zagrożonych marginalizacją, podopiecznych pomocy społecznej, osób niepełnosprawnych, projekty wspierające wysoką jakość oświaty i szkolnictwa wyższego oraz ich dostosowanie do potrzeb rynku pracy, działania na rzecz profilaktyki zdrowotnej, wysokiej jakości ochrony zdrowia i kompetentnych kadr medycznych (Szczegółowy..., 2017). Jego realizacja umożliwia także testowanie innowacyjnych inwestycji społecznych.

Również RPO - w ramach projektów o charakterze społecznym - realizują inwestycje społeczne w zdiagnozowanych obszarach potrzeb wyodrębnionych w konkretnych regionach. Dotyczą one m.in. pomocy dla osób poszukujących pracy i tworzenia nowych miejsc pracy, rozwijania instrumentów godzenia życia zawodowego i rodzinnego, działań na rzecz włączenia społecznego, dostępu do wysokiej jakości usług społecznych, zdrowotnych i edukacyjnych, dostosowania systemu edukacji do wymogów rynku pracy, wsparcia uczenia się przez całe życie czy rozwoju gospodarki społecznej.

Można więc wskazać, że wiele świadczeń i usług o charakterze inwestycji społecznych rozwija są dzięki wykorzystaniu EFS, które - wskazując na realizację kluczowych celów unijnej polityki społecznej - wymagają tego typu działań. Polityka społeczna UE stanowi więc, po pierwsze, czynnik kreujący inwestycje społeczne w Polsce, po drugie, swoisty łącznik rozwiązań z zakresu polityki społecznej, stosowanych w poszczególnych państwach członkowskich.

Czynnikiem mobilizującym państwa członkowskie, w tym Polskę, do wdrożenia podejścia inwestycyjnego jest system wskaźników obrazujący osiągnięte cele w dziedzinie rozwoju społecznego. Obejmuje on nie tylko mierniki wskazane w tabeli 1, a więc odnoszące się do aktywności zawodowej, edukacji i walki z ekskluzją społeczną, ale także szereg wskaźników dostosowanych do specyfiki poszczególnych programów operacyjnych. Tylko w przypadku POWER opracowanych zostało kilkadziesiąt wskaźników rezultatu bezpośredniego, obrazujących osiągnie celów dzięki interwencji EFS. Każdy z 16 RPO dysponuje specyficznymi miernikami odnoszącymi się do mierzenia poziomu rozwoju społecznego. Ich wartość, a więc stopień realizacji założonych celów, będzie można ocenić dopiero na koniec roku 2023, który będzie rokiem sprawozdawczym i rozliczeniowym dla wszystkich programów operacyjnych. Można tutaj sformułować przypuszczenie, że instytucje zarządzające POWER i RPO dołożą wszelkich starań na rzecz osiągnięcia wskazanych wartości, ponieważ jest to 
skorelowane z ostatecznym rozliczeniem z Komisją Europejską przyznanych Polsce funduszy.

Specyfiką polskiego podejścia do polityki społecznej jest korzystanie z rozwiązań w postaci transferów społecznych, które nie tylko uzupełniają świadczenia i usługi inwestycyjne, ale i same uważane są za inwestycje (MRPiPS, 2017). Oczywiście koncepcja inwestycji społecznych nie wyklucza z rozwiązań inwestycyjnych świadczeń pieniężnych, wręcz wskazuje, że do inwestycji społecznych zaliczyć można różnorodne świadczenia, usługi czy rozwiązania prawne, które wspierają obywateli i przynoszą pozytywne skutki społeczne. Głównym aspektem jest nacisk na zwrot społeczny i gospodarczy stosowanych rozwiązań w odróżnieniu od tradycyjnych transferów społecznych, których głównym celem jest zabezpieczenie odpowiednich warunków bytu obywateli (Midgley, 2017; Hemerijck, 2013; Morel i in., 2015). W tym kontekście inwestycyjność stosowanych w Polsce transferów staje się dyskusyjna, bowiem pełnią one głównie funkcje zabezpieczające przed ubóstwem i zapewniające zaspokojenie potrzeb.

\section{PODSUMOWANIE}

Podejście inwestycyjne nie wytycza głównych kierunków działań w polskiej polityce społecznej, jednakże traktowanie polityki społecznej jako inwestycji, która się opłaca, przyniesie w przyszłości zyski społeczne i ekonomiczne, coraz częściej pojawia się przy okazji projektowania i wdrażania nowych rozwiązań. Z pewnością sprzyja temu polityka inwestycyjna promowana przez UE i stosowana w ramach rozwiązań współfinansowanych z funduszy europejskich. Wsparcie finansowe ze strony UE odgrywa kluczową rolę w kreowaniu, testowaniu i upowszechnianiu inwestycji społecznych. Uznać je można za najistotniejszy element europeizacji polityki społecznej w Polsce, w kontekście realizacji paradygmatu inwestycyjnego. Stąd stwierdzić należy, że polskie podejście do inwestycji społecznych jest wynikiem implementacji koncepcji inwestycji społecznych wypracowanej w ramach UE i wdrażanej z wykorzystaniem środków europejskich. Europeizacja przejawia się również w podejściu do strategicznego planowania w sferze polityki społecznej, w której obecne strategie i programy działań są kompatybilne z wytycznymi UE, a projektowane i wdrażane działania mają również charakter wyprzedzający, a nie tylko korygujący i reaktywny. Wsparcie dla paradygmatu inwestycyjnego ma odzwierciedlenie nie tylko w zasadach finansowania programów rozwojowych przez fundusze strukturalne, w tym 
głównie EFS, ale także w systemie wskaźników, które państwa są zobowiązane osiągać, odzwierciedlających zachodzące zmiany społeczne. Odnoszą się one nie tylko do nadrzędnych, ogólnounijnych celów strategicznych, ale także do poszczególnych programów operacyjnych współfinansowanych przez EFS. Ich skuteczność nie tylko w przypadku Polski, ale wszystkich państw korzystających z EFS, będzie można ocenić dopiero po zakończeniu rozliczenia perspektywy 2014-2020, czyli zgodnie z zasadą n+3 w 2023 roku.

Jednocześnie w polskiej polityce społecznej silne jest dążenie do uzupełniania usług inwestycyjnych transferami społecznymi i rozwiązaniami o charakterze zabezpieczającym i ochronnym. Wskazuje to na dualizm rozwiązań - z jednej strony obserwujemy coraz częstsze sięganie do inwestycji społecznych jako rozwiązań produktywnych, przynoszących zarówno społeczny, jak i ekonomiczny zwrot, z drugiej zaś wykorzystywanie tradycyjnych instrumentów polityki społecznej. Owa koegzystencja różnego typu działań stanowi o specyfice realizowanej polityki społecznej, w której pojęcie inwestycji używane jest często dla podkreślenia prognozowanego pozytywnego wpływu proponowanych rozwiązań na kapitał ludzki, bez analizy faktycznej inwestycyjności działań w perspektywie społecznej i gospodarczej.

W konkluzji należy stwierdzić, iż procesy europeizacyjne w odniesieniu do wdrożenia podejścia inwestycyjnego do narodowych polityk społecznych państw UE nie są zbyt zaawansowane. Państwa nadal zachowują daleko posuniętą suwerenność w doborze celów rozwoju społecznego, a także metod ich realizacji. Implementacja OMK w realizacji strategii Europa 2020 i PIS stanowi zachętę do wdrożenia paradygmatu inwestycyjnego, ale nie ma wiążącego charakteru. Stąd obserwować i przewidywać można różny stopień implementacji tego paradygmatu do polityk społecznych państw członkowskich UE. Istotnym instrumentem realizacji podejścia inwestycyjnego jest EFS, który stanowi najważniejszy instrument europeizacji zarządzania rozwojem społecznym państw.

Stosując typologię I. Bache, która odnosi się do typów reakcji, jakie wykazują państwa w odpowiedzi na procesy europeizacyjne, przypadek Polski można określić jako absorbcję, która polega na przyjmowaniu przez państwo rozwiązań płynących z poziomu ponadarowego, bez znaczącej zmiany podstaw realizacji dotychczasowej polityki (Bache, 2008, s. 5). Jednocześnie podkreślić należy, że głównym podmiotem polityki społecznej, bez względu na realizowany paradygmat, nadal pozostają państwa, bowiem to one ponoszą główne koszty realizacji działań społecznych, a co za tym idzie - rezerwują sobie prawo do podejmowania kluczowych decyzji w tym zakresie (Morel i in., 2015). 
Bibliografia:

Armstrong, K.A. (2010). Governing Social Inclusion: Europeanization through Policy Coordination. Oxford: Oxford University Press.

Bache, I. (2008). Europeanization and Multi-Level Governance: Empirical Findings and Conceptual Challenges, ARENA Working Papers, 16. Pobrano z: http://www.sv.uio. no/arena/english/research/publications/arena-working-papers/2001-2010/2008/ wp08_16.pdf.

Bonoli, G. (2005). The Politics of the New Social Policies: Providing Coverage Against New Social Risks in Mature Welfare States. Policy \& Politics, 33(3), 431-449.

Borrás S., Jacobsson K. (2004). The Open Method of Co-Ordination and the new Governance Patterns. Journal of European Public Policy, 11(2), 185-208.

Buller J., Gamble A. (2002). Conceptualising Erupeanization. Public Policy and Administration, $17(2), 1-22$.

D’Addato A., Williams A. (2013). Inspirujące praktyki w zakresie wczesnej interwencji i profilaktyki w działaniach na rzecz rodziny i wsparcia dla rodziców w Europie. Dziecko krzywdzone, 2(12), 5-10.

EC (2013). Towards Social Investment for Growth and Cohesion - Including Implementing the European Social Fund 2014-2020. Brussels: European Commission. Pobrane z: http://eur-lex.europa.eu/LexUriServ/LexUriServ.do?uri=COM:2013:0083:FIN:e$\mathrm{n}: \mathrm{PDF}$.

EC (2018). Social investment. Brussels: European Commission. Pobrane z: http:// ec.europa.eu/social/main.jsp?catId=1044.

Exadactylos, T., Radaelli, C. (2009). Research Design in European Studies: The Case of Europeanization. JCMS, 47(3), 507-530.

Grewińki, M. (2015). Inwestycyjna polityka społeczna oparta na usługach. W kierunku nowego modelu welfare state. W: M. Grewiński, A. Karwacki (red.). Inwestycyjna Polityka Społeczna (s. 58-76). Warszawa: Wyższa Szkoła Pedagogiczna im. J. Korczaka.

Hemerijck, A. (2013). Changing Welfare States. Oxford: Oxford University Press.

Innovative Social Investment Strenghtening Communities in Europe. Pobrane z: http:// innosi.eu.

Klimowicz, M., Michalewska-Pawlak M., Moroń D. (2018). Inwestycje społeczne w Polsce na tle wybranych rozwiązań europejskich. Studia Europejskie, 1, 161-178.

Ladrech, R. (2010). Europeanization and National Politics. Basingstoke: Palgrave Macmillan.

Leibetseder, B. (2017). Social Investment Policies and the European Union: Swimming Against the Neoliberal Tide? Comparative European Politics, 1-21. DOI: https://doi. org/10.1057/s41295-016-0086-2.

Lisbon European Council (2000). Presidency Conclusions. Pobrane z: http://www. europarl.europa.eu/summits/lis1_en.htm.

KE (2010). Strategia na rzecz inteligentnego i zrównoważonego rozwoju sprzyjającego włączeniu społecznemu. KOM(2010) 2020, Bruksela, 3.3.2010. 
MAiC (2013). Polska 2030. Trzecia fala nowoczesności. Długookresowa Strategia Rozwoju Kraju. Warszawa:. Ministerstwo Administracji i Cyfryzacji. Pobrane z: http://www. kigeit.org.pl/FTP/PRCIP/Literatura/002_Strategia_DSRK_PL2030_RM.pdf .

Michalewska-Pawlak, M. (2017). Unia Europejska wobec paradygmatu inwestycji społecznych. Wrocławskie Studia Politologiczne, 23, 93-107.

Midgley, J. (2017). Social Investment: Concepts, Uses and Theoretical Perspectives. W: J. Midgley, E. Dahl, A.C. Wright (red.). Social Investment and Social Welfare: International and Critical Perspectives (s. 13-32). Cheltenham, Northampton: Edward Elgar Publishing.

MKiDN (2013). Strategia Rozwoju Kapitału Społecznego 2020. Warszawa: Ministerstwo Kultury i Dziedzictwa Narodowego. Pobrane z: http://prawo.sejm.gov.pl/isap.nsf/ download.xsp/WMP20130000378/O/M20130378.pdf.

Morel, N., Palier, B., Palme, J. (2015). Paradygmat inwestycji społecznych: w poszukiwaniu nowego modelu ekonomicznego i mobilizacji politycznej. W: N. Morel, B. Palier, J. Palme (red), Polityka społeczna jako inwestycja (s. 355-379). Warszawa: Wyższa Szkoła Pedagogiczna im. Janusza Korczaka.

Moroń, D., Klimowicz, M. (2017). Zastosowanie stopy społecznego zwrotu z inwestycji (SROI) jako wskaźnika mierzenia efektywności projektów społecznych. Wrocławskie Studia Politologiczne, 21, 67-81.

MPiPS (2013a). Strategia Rozwoju Kapitału Ludzkiego 2020. Warszawa: Ministerstwo Pracy i Polityki Społecznej. Pobrane z file://D:/Temp/Strategia Rozwoju Kapitału Ludzkiego 2020.pdf.

MPiPS (2013b). Krajowy Program Przeciwdziałania Ubóstwu i Wykluczeniu Społecznemu 2020. Nowy wymiar aktywnej integracji, Warszawa: Ministerstwo Pracy i Polityki Społecznej. Pobrane z: http://www.ois.wzp.pl/attachments/article/224/ uwagi\%20WUP.pdf.

MPiPS (2013c). Założenia Długofalowej Polityki Senioralnej w Polsce na lata 2014-2020. Warszawa: Ministerstwo Pracy i Polityki Społecznej. Pobrane z file://C:/Users/ PRACOW 1/AppData/Local/Temp/ZDPS\%2014-02-04\%20\%20Monitor\%20 Polski-2.pdf.

MPiPS (2015). Krajowy Plan Działań na rzecz Zatrudnienia na lata 2015-2017. Warszawa: Ministerstwo Pracy i Polityki Społecznej. Pobrane z: https://www.mpips. gov.pl/gfx/mpips/userfiles/_public/1_NOWA\%20STRONA/rynek\%20pracy/ programy\%20i\%20sprawozdania/KPDZ_2015-2017_marzec_2015.pdf.

MR (2017). Szczegółowy Opis Osi Priorytetowych Programu Operacyjnego Wiedza Edukacja Rozwój 2014-2020. Wersja 10. Warszawa: Ministerstwo Rozwoju.

MRPiPS (2017). Rodzina najlepsza inwestycją. Warszawa: Ministerstwo Rodziny, Pracy i Polityki Społecznej. Pobrane z: file://D:/Temp/Rodzina_najlepsza_inwestycja_28-09.pdf.

MRPiPS. Europejski Fundusz Społeczny, Pobrane z: https://www.mpips.gov.pl/fundusze-europejskie/europejski-fundusz-spoleczny. 
MRR (2012). Strategia Rozwoju Kraju 2020. Warszawa: Ministerstwo Rozwoju Regionalnego. Pobrane z: https://rpo.slaskie.pl/media/files/cms/DOKUMENTY STRATEGICZNE/Strategia Rozwoju Kraju 2020.pdf.

Mucha-Leszko, B. (2016). Polityka społeczna jako instrument spójności Unii Europejskiej, Nierówności Społeczne a Wzrost Gospodarczy, 47(3), 193-204, DOI:10.15584/ nsawg.2016.3.14.

PE (2012). Rezolucja Parlamentu Europejskiego z dnia 20 listopada 2012 r. $w$ sprawie paktu na rzecz inwestycji społecznych - reakcja na kryzys. Parlament Europejski (2012/2003(INI)).

PE i Rada UE (2013). Rozporzadzenia Parlamentu Europejskiego i Rady (UE) nr 1303/2013 z dnia 17 grudnia 2013 r. ustanawiajace wspólne przepisy dotyczace Europejskiego Funduszu Rozwoju Regionalnego, Europejskiego Funduszu Społecznego, Funduszu Spójności, Europejskiego Funduszu Rolnego na rzecz Rozwoju Obszarów Wiejskich oraz Europejskiego Funduszu Morskiego i Rybackiego oraz ustanawiajace przepisy ogólne dotyczące Europejskiego Funduszu Rozwoju Regionalnego, Europejskiego Funduszu Społecznego, Funduszu Spójności i Europejskiego Funduszu Morskiego i Rybackiego oraz uchylajace rozporzadzenie Rady (WE) nr 1083/2006, Dz.U. L 347 z 20.12.2013.

Pazderski, F. (2017). Innowacyjne inwestycje społeczne. W poszukiwaniu efektywnych odpowiedzi na wyzwania naszych czasów. Warszawa: Instytut Spraw Publicznych. Pobrane z: http://www.isp.org.pl/uploads/pdf/622010832.pdf.

Pietrzyk, M. (2014). Otwarta metoda koordynacji-soft law w obszarze walki z ubóstwem i wykluczeniem społecznym, W: E. Rutkowska-Tomaszewska, L. Klat-Wertelecka, J. Blicharz (red.). Ubóstwo w Polsce (s. 217-225). Wrocław: E-Wydawnictwo. Prawnicza i Ekonomiczna Biblioteka Cyfrowa. Wydział Prawa, Administracji i Ekonomii Uniwersytetu Wrocławskiego. Pobrane z: http://www.bibliotekacyfrowa. pl/Content/51748/20_Marcin_Pietrzyk.pdf.

Portal Funduszy Europejskich. Pobrane z: https://www.funduszeeuropejskie.gov.pl/.

Strategia Europa 2020. System Monitorowania Rozwoju STRATEG, Pobrane z: http:// strateg.stat.gov.pl/Home/Strateg.

Ruszkowski, J. (2007). Wstęp do studiów europejskich. Warszawa: Wydawnictwo Naukowe PWN. Szarfenberg, R. (2014). Polityka społeczna Unii Europejskiej przewodnik. Pobrane z: http://www.eapn.org.pl/wp-content/uploads/2014/07/ przewodnik_www.pdf.

Wersja skonsolidowana Traktatu o Funkcjonowaniu Unii Europejskiej. Pobrane z: http:// oide.sejm.gov.pl/oide/index.php?option=com_content\&view=article\&id=14804\&Itemid $=946$.

Wiktorska-Święcka, A., Klimowicz M., Michalewska-Pawlak M., Moroń D., Pazderski F. (2015). Innosi policy review and cross European comparative research: Poland, D2.3 Report on best practices. Brussels: European Commission, Research Executive Agency. 
Wiktorska-Święcka, A., Klimowicz, M., Michalewska-Pawlak, M., Moroń, D. (2016). Report on approaches to social investment from the scientific perspective (InnoSI). WP2: State of Art: Deliverable D2.2. Brussels: European Commission, Research Executive Agency.

Wiktorska-Święcka, A., Klimowicz, M., Michalewska-Pawlak, M., Moroń, D. (2017). Inwestycje społeczne jako paradygmat polityk publicznych w Unii Europejskiej. Warszawa: Wydawnictwo Naukowe Scholar. 